\title{
A Statement on Behalf of the Editorial Board of Vetus Testamentum
}

We are deeply disturbed to hear of the recent conviction of Prof. Jan Joosten on charges of possessing child pornography. We repudiate in the strongest terms possible this violent and disgusting exploitation of human beings, and we regret the lasting and irrevocable harm that his actions have inflicted upon an untold number of vulnerable people. We are shocked and saddened at the revelations that our former colleague was not the person we thought he was.

As an editorial board we understand our mandate to be vetting and publishing the finest biblical studies scholarship. But we recognize that our responsibility to highlight and promote excellent biblical scholarship is part of our larger responsibility to protect and nurture our fellow human beings. For this reason, we have acted quickly to remove Joosten from any and all activities affiliated with Vetus Testamentum. Although his term as Editor-in-Chief of Vetus Testamentum ended on Dec. 31, 2019, he remained on the board until June 23, 2020 , when we removed him summarily from the journal's editorial board, including removing him from the list of the journal's reviewers.

Joosten has also been removed as General Secretary of IOsOT, and replaced by Prof. Annette Schellenberg. Although these actions cannot begin to alleviate the deep harm brought about by the abuse in which Joosten has admitted participation, we hope through our actions to promote a more just, equitable, and life-affirming guild that views all people as deserving of respect, care, and the opportunity to thrive.

Annette Schellenberg, Editor-in-Chief, Vetus Testamentum

Jeremy Hutton, Associate Editor, Vetus Testamentum

Joachim Schaper, Book Review Editor, Vetus Testamentum

Christl M. Maier, Editor-in-Chief, Supplements to Vetus Testamentum 